\title{
KOSMETOLOGŲ NUOMONE APIE APSAUGINIŲ VEIDO KAUKIŲ DE்VE்JIMO SUKELTŲ ODOS PROBLEMŲ SPRENDIMO BŪDUS
}

\author{
Loreta Valatkevičienė, Žaneta Mickienė, Emilija Petruškevičiūtė \\ Kauno kolegija, Medicinos fakultetas
}

Raktažodžiai: kosmetologai, nuomonè, apsauginès veido kaukès, odos problemos.

\begin{abstract}
Santrauka
2020 m. kovo mèn. Pasaulio sveikatos organizacija paskelbė COVID-19 pasaulinę pandemiją. Ilgą laiką dèvimos veido apsaugos kaukès gali sukelti odos problemų. Tai aktualu žmonėms, kuriems privalomas veido apsaugos priemonių dèvejjimas. Tyrimo tikslas - atskleisti kosmetologų nuomonę apie veido apsaugos kaukių dèvẻjimo sukeltų odos problemų sprendimo būdus. Tyrimo metu nustatyta, jog kosmetologų klientams, turintiems riebią arba probleminę odą, veido kaukių dèvèjimas dažniausiai sukèlė odos kuperozę, dehidrataciją ir paprastuosius spuogus ar šių susirgimų paūmèjimą. Respondentai dažniausiai rekomendavo drékinamąsias, uždegimo slopinamąsias ir antibakterines priemones. Esant uždegiminei odos būklei, rekomendavo apsilankyti pas gydytoją dermatologą.
\end{abstract}

\section{Ivadas}

$2020 \mathrm{~m}$. Pasaulio sveikatos organizacijai paskelbus COVID-19 pasaulinę pandemiją, siekiant sumažinti viruso plitimą oro lašelių būdu, daugumoje pasaulio valstybių įsigaliojo privalomas veido kaukès dèvejimas ne tik sveikatos priežiūros darbuotojams, bet ir plačiajai visuomenei [1]. Pirminè veido kaukių paskirtis yra pacientų apsauga nuo sveikatos priežiūros darbuotojų iškvepiamų mikroorganizmų, taip sumažinant žaizdų infekcijos tikimybę [2]. İtemptu COVID-19 pandemijos laikotarpiu asmens apsaugos priemoniu naudojimas mažina viruso plitimą, žmogaus perduodamą žmogui. Visuomenejje, kurioje gyvename, socialiniai kontaktai yra pagrindinis bakterijų ir virusų perdavimo būdas [3]. Veido kaukių dèvèjimas yra labai svarbus, siekiant sumažinti COVID-19 perdavimą tuo laikotarpiu, kai trūksta efektyvių priemonių mažinti viruso plitimą - skiepų, kurie suteiktų kolektyvinị imunitetą visuomenei. Apsauginès veido kaukès yra vienkartinès, priklausomai nuo rūšies, susidedančios iš plonų trijų-penkių polipropileno sluoksnių, su vienu ar dviem filtrais, neleidžiančiais prasiskverbti didesnei nei 1 mikrono medžiagai, todèl sulaiko tokio ar didesnio dydžio bakterijas [2]. Priklausomai nuo audinio rūšies ir sluoksnių, medžiaginès veido kaukès leidžia odai lengviau kvėpuoti bei suteikia didesnį komfortą, priglusdamos prie veido. Netinkamas jų dẻvèjimas gali sukelti nepageidaujamų odos problemų. Ilgo dèvèjimo metu išskiriamas prakaitas, išorinè drègmè drékina kaukès audinius, sudaro sąlygas plisti bakterijoms, didina dangalo svorị bei sukibimą tarp medžiagos ir veido odos, todèl atsiranda lipnus pojūtis ir didejja trinties koeficientas. Dèl glaudaus kontakto ir ilgesnio trinties laiko galimas odos sudirginimas, įbrèžimai ar kiti odos sužalojimai. Asmenims, kurių oda linkusi ị alergines reakcijas, jos gali išsivystyti dèl odą dirginančių kaukès sudètinių dalių [4].

Ilgą laiką dèvint apsaugines kaukes, gali atsirasti arba paūmèti odos problemos [5]. Ilgainiui kaukių dèvejimas valstybėse buvo suvoktas kaip nepatogus, nemalonus apsaugos metodas, keliantis nerimą, kad ilgalaikis jų dèvejjimas netgi nesveikas ir pavojingas [6]. Po ilgalaikio kaukių dèvejjimo atliktuose tyrimuose vis dažniau pranešama apie odos problemų atsiradimą arba paūmèjimą [5,7]. Odos problemas provokuojančių veiksnių yra daug, iš kurių vienas - ilgalaikis netinkamas apsauginès kaukès dèvejjimas. Tai aktualus klausimas ir opi problema žmonėms, kuriems privalomas veido apsaugos priemonių dèvèjimas, keliantis odos problemų, kurių galètų išvengti padedami specialistų ir naudodamiesi suteiktomis rekomendacijomis. Esant sudètingai odos būklei, kosmetologijos specialistų kompetencija neleidžia imtis kosmetinių ar aparatinių procedūrų, sprendžiant apsauginių veido kaukių dèvėjimo sukeltas odos problemas, todèl specialistai privalo rekomenduoti apsilankyti pas specializuotus odos gydytojus.

Tyrimo tikslas - atskleisti kosmetologų nuomonę apie apsauginių veido kaukių dèvejjimo sukeltų odos problemų sprendimo būdus. 


\section{Tyrimo objektas ir metodas}

Tyrimo objektas - kosmetologų nuomonė apie apsauginių veido kaukių dèvèjimo sukeltų odos problemų sprendimo būdus. Atliktas kokybinis tyrimas, taikant anketinès apklausos metodą. Internetinę anoniminę anketą sudare 21 pusiau uždaro tipo klausimas su vienu arba keliais galimais atsakymo variantais. Klausimai sudaryti remiantis moksline ir profesine literatūra. Pirmąą anketos dalį sudarè klausimai, skirti įvertinti kosmetologų bei jų klientų sociodemografinius duomenis. Antroji anketos dalis skirta išsiaiškinti kosmetologų nuomonę apie klientu dèvimų apsauginių veido kaukių rūšis ir dažniausias paūmejjusias arba naujas veido odos problemas, dèl jų atliekamas kosmetologines procedūras, apsauginių veido kaukių dèvèjimo trukmę, odos būklę bloginančius veiksnius, susijusius su apsauginėmis veido kaukèmis, specialistų teikiamą papildomą informaciją bei apsauginių veido kaukių dèvejjimo rekomendacijas.

Anoniminè anketa buvo pateikta kosmetologų grupèms socialiniuose tinkluose ir atsitiktine tvarka išsiųsta specialistams asmeniškai. Tyrimas atliktas $2021 \mathrm{~m}$. vasario-balandžio mėnesiais. Tyrime dalyvavo 50 moteriškosios lyties respondentų. Didžiosios dalies respondentų darbo patirtis siekè 6-10 metų (74 proc.). Didžiausia dalis respondentų (82 proc.) turèjo aukštajị neuniversitetinį išsilavinimą, 44 proc. respondentų gyvenamoji vieta buvo didmiestis.

\section{Tyrimo rezultatai ir jų analizė}

Didžioji dalis ( 88 proc.) respondentų nurodè, jog dažniausiai klientų amžius yra 31-50 metų. Tokio amžiaus žmonių darbas reikalauja dèvèti apsaugines veido kaukes visą

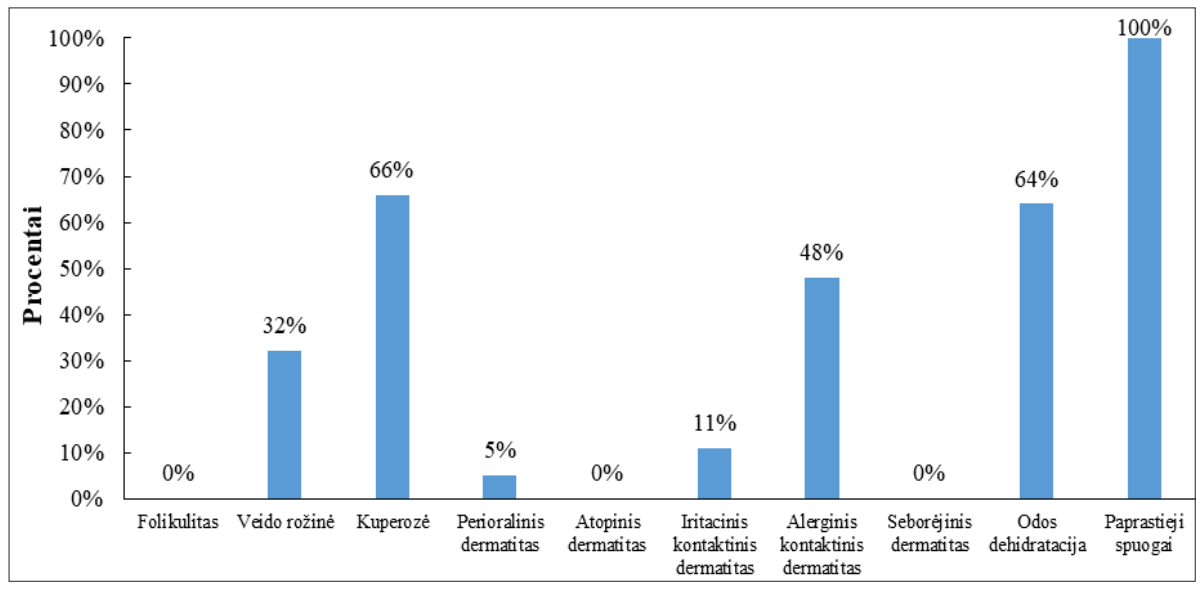

1 pav. Apsauginių veido kaukių keliamos odos problemos $(n=50)$

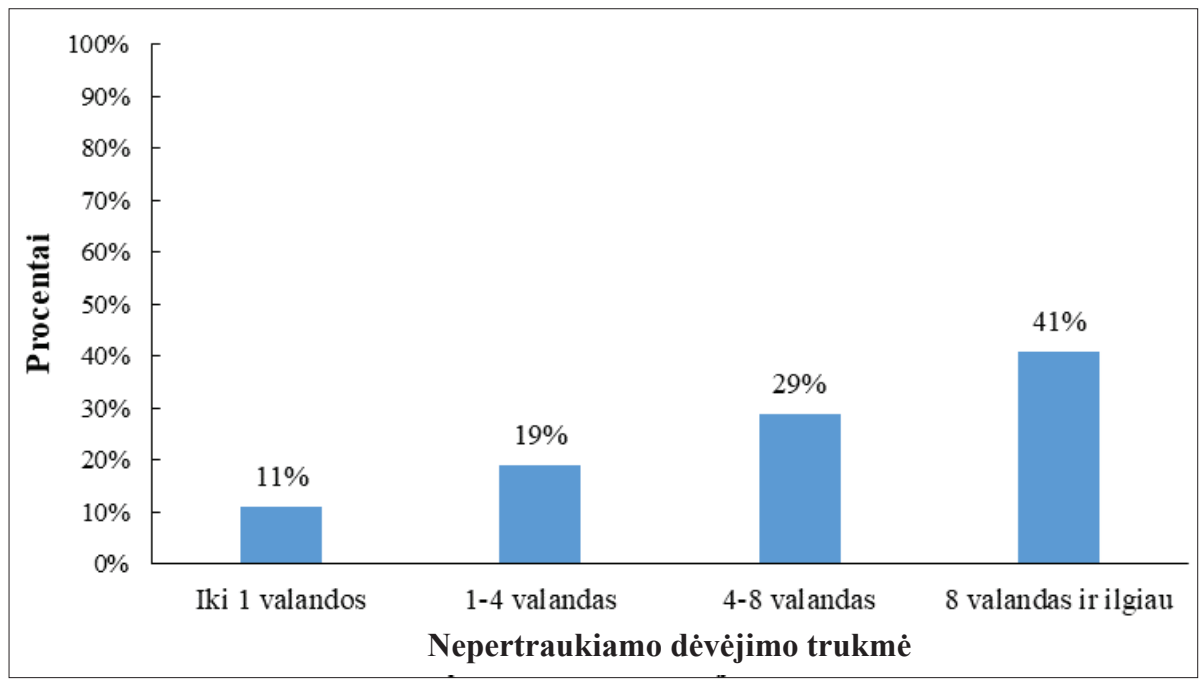

2 pav. Apsauginių veido kaukių nepertraukiamo dèvėjimo trukmè $(n=50)$ 
darbo pamainą, tad ir odos problemų pasitaiko gerokai daugiau. Dažniausiai dėvimos vienkartinès medicininès veido kaukès (70 proc.) ir filtruojamosios puskaukès - respiratoriai (54 proc.), kurios yra vienkartinio naudojimo, pasižyminčios aukštu apsaugos koeficientu.

Kosmetologijos kabinete dažniausiai lankosi klientai, susidūrę su kuperozès (66 proc.), odos dehidratacijos (64 proc.) ir paprastujų spuogų (100 proc.) atsiradimu arba paūmèjimu (1 pav.). Atliktų tyrimų duomenimis, šios problemos dažniausiai pasireiškia apsaugines kaukes devintiems asmenims dèl sukeltos aukštos temperatūros, bakterijų dauginimosi nepralaidžioje plèvelèje tarp veido ir kaukès [8-10].

Paklausus respondentų, kiek laiko jų klientai nepertraukiamai dèvi apsaugines veido kaukes, nemaža apklaustujų dalis (41 proc.) atsaké, jog nepertraukiamas kaukių dèvejimas sudaro 8 valandas ir net ilgiau (2 pav.). Esant tokiai nepertraukiamai kaukès dèvejjimo trukmei, dèl fizinio judèjimo, kalbẻjimo, skysčių išsiskyrimo, kyla didelè odos sudirginimo rizika. Galima daryti prielaidą, kad pagrindinè sudirginimo priežastis - dèl susidariusios nepralaidžios plèvelès tarp kaukès ir veido padidejusi temperatūra, o taip pat kaukių dèvejimo laiko viršijimas.

Vieną iš pagrindinių veiksnių, galinčių bloginti odos būklę kaukių dèvejjimo laikotarpiu, respondentai nurodè apsauginių veido kaukių dèvėjimo rekomendacijų nepaisymą (86 proc.), (3 pav.). Kita dalis respondentų mano, jog tai dekoratyvinè kosmetika, ypač aktuali moterims. Alergines odos reakcijas sukeliančios medžiagos (32 proc.) bei prasta burnos higiena (10 proc.) buvo nurodyti kaip mažiausiai odos būklę bloginantys veiksniai. Tai parodo, jog kosmetologai žino daugumą odos būklę bloginančių veiksnių, tačiau kai kurie rečiau aprašomi ir diskutuotini veiksniai jiems nèra aiškūs, todèl šių veiksnių išmanymas priklauso nuo kosmetologų profesinio domejimosi šia sritimi.

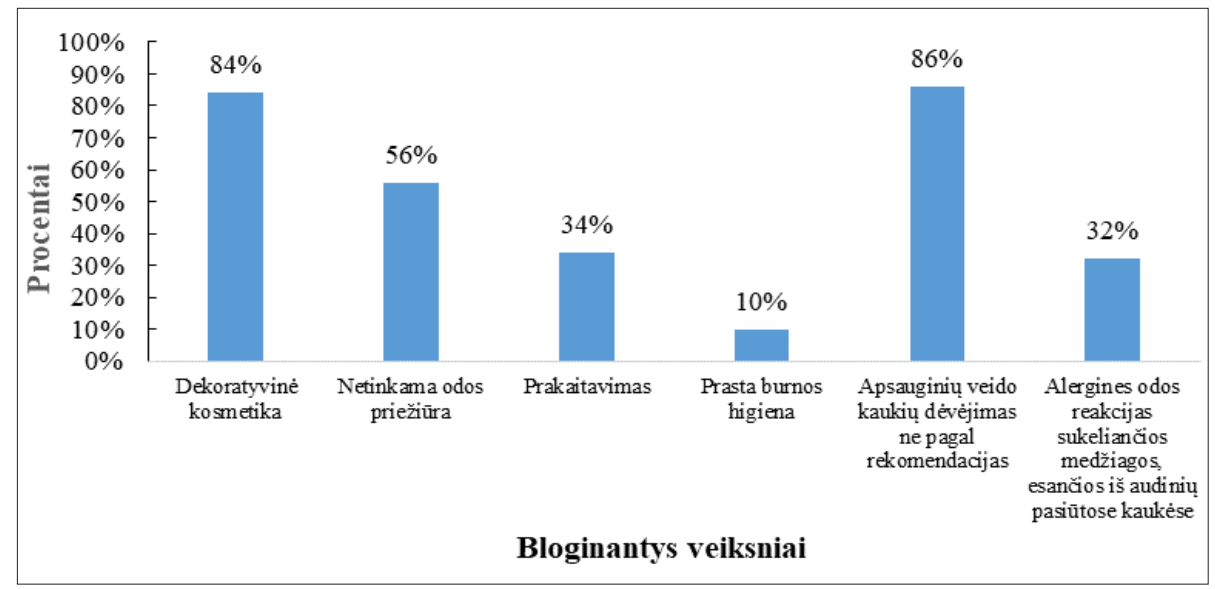

3 pav. Odos būklę bloginantys veiksniai $(n=50)$

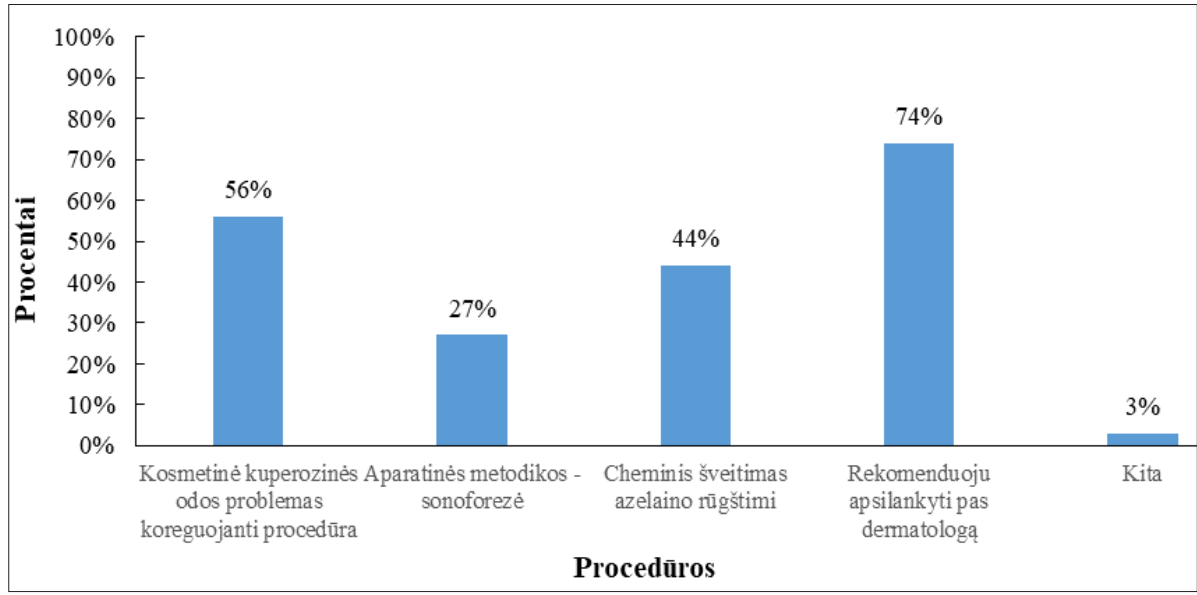

4 pav. Procedūrų pasirinkimas, sprendžiant kuperozės problemą $(n=50)$ 


\section{4}

Spręsdami kuperozės paveiktos odos problemas, respondentai dažniausiai rekomenduoja klientams apsilankyti pas gydytoją dermatologą (74 proc.), kuris įvertintų odos būklę ir pagal poreiki sudarytų odos gydymo planą. Kitu atveju, dauguma kosmetologų renkasi atlikti kosmetines kuperozinès odos procedūras (4 pav.).

Sprendžiant dehidratacijos paveiktos odos problemas, dažniausiai pasirenkamos kosmetinès dehidratuotos odos procedūros (64 proc.) arba cheminis šveitimas (pvz., pieno rūgštimi), (57 proc.). Apsauginių kaukių dèvejimo laikotarpiu kosmetiniu procedūru parinkimas yra itin svarbus, kad atliekamos procedūros nesukeltų šalutinio poveikio (5 pav.).

Spręsdami paprastuju spuogų problemą, respondentai dažniausiai renkasi mechaninio odos valymo procedūrą, kuri laikoma saugi (77 proc.), arba rekomenduoja klientui apsilankyti pas gydytoją dermatologą (61 proc.) įvertinti odos būklę ir grịžti pas kosmetologą gerinti liekamujų reiškinių būklę (6 pav.).

Visi respondentai nurodè, jog esant uždegiminei odos būklei, rekomenduoja klientams apsilankyti pas gydytoją dermatologą (100 proc.). Spręsdami dehidruotos odos problemas, apklaustieji rekomenduoja papildomai namuose naudoti drèkinamojo poveikio priemones (68 proc.), kuperozinei odai tinkamiausios raminamojo ( 58 proc.), stiprinamojo (70 proc.) bei uždegimo slopinamojo (53 proc.) poveikio priemonès, nes reikia mažinti odos uždegimą, o paprastujų spuogų problemai spręsti papildomai rekomenduojamos uždegimo slopinamojo, antibakterinio poveikio priemonès, kadangi svarbu neutralizuoti uždegimo sukèlèją.

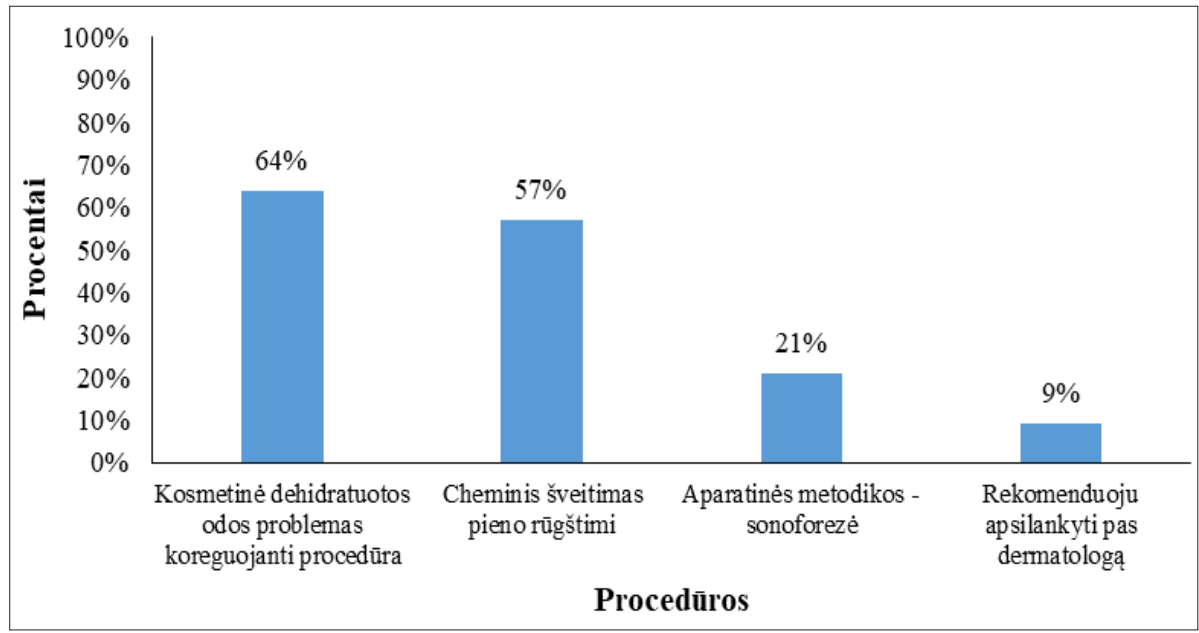

5 pav. Procedūrų pasirinkimas, sprendžiant dehidratacijos problemą $(n=50)$

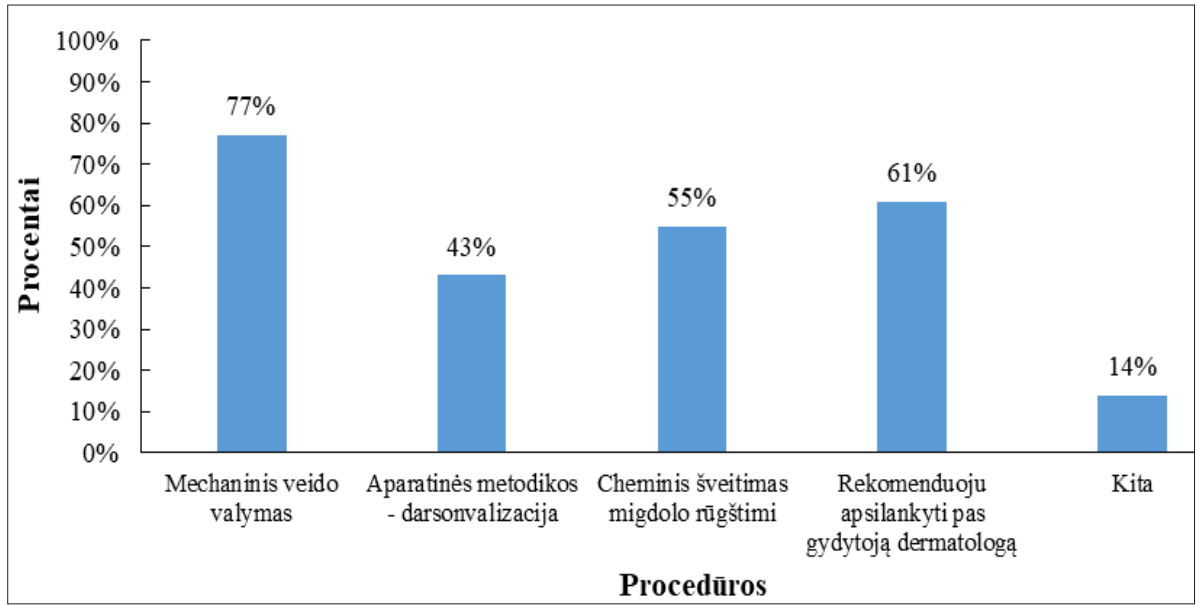

6 pav. Procedūrų parinkimas, sprendžiant paprastujų spuogų problemą $(n=50)$ 


\section{Išvados}

1. Didžioji dalis 31-50 metų asmenų patiria odos problemų, susijusių su ilgalaikiu apsauginių veido kaukių dèvèjimu.

2. Apsauginių veido kaukių dėvëjimas sukelia arba suaktyvina odos dehidratacijos, kuperozès bei paprastujų spuogų problemas, kurias galima spręsti klasikinėmis ir aparatinėmis procedūromis bei cheminiu šveitimu, pritaikant aktyvius ingredientus. Dažnai rekomenduojamos namuose naudoti drèkinamojo, uždegimo slopinamojo bei antibakterinio poveikio priemonès.

3. Kosmetologai tokio tipo veido odos problemas sprendžia patys arba, esant uždegiminei ligai, rekomenduoja apsilankyti pas gydytojus dermatologus. Didžioji dalis kosmetologų išmano odos būklę bloginančius veiksnius ir teikia papildomas odos problemų paūmèjimo prevencijos rekomendacijas.

\section{Literatūra}

1. World Health Organization. COVID - 19 Technical Specifications for personal protective equipment, list of standarts and checklist. https://www.who.int/publications/m/item/technicalspecs-PPE-Covid19-07082020

2. Vincent M, Edwards P. Disposable surgical face masks for preventing surgical wound infection in clean surgery. Cochrane Database Syst Rev 2016;4(4):CD002929. https://doi.org/10.1002/14651858.CD002929.pub3

3. Matuschek C, Moll F, Fangerau H, Fischer JC, Zänker K, van Griensven M, Schneider M, et al. The history and value of face masks. Eur J Med Res 2020;25:23. https://doi.org/10.1186/s40001-020-00423-4

4. Tang KM, Chau KH, Kan CW, Fan JT. Assessing the accumulated stickiness magnitude from fabric-skin friction: effect of wetness level of various fabrics. R Soc Open Sci 2018;5(8):180860. https://doi.org/10.1098/rsos.180860

5. Garcia Godoy LR, Jones AE, Anderson TN, Fisher CL, Seeley KML, Beeson EA, Zane HK, Peterson JW, Sullivan PD. Facial protection for healthcare workers during pandemics: a scoping review. BMJ Glob Health 2020;5(5):e002553.

https://doi.org/10.1136/bmjgh-2020-002553

6. Scheid JL, Lupien SP, Ford GS, West SL. Commentary: Physiological and Psychological Impact of Face Mask Usage during the COVID-19 Pandemic. Int J Environ Res Public Health 2020;17(18):6655.

https://doi.org/10.3390/ijerph17186655
7. Parida SP, Bhatia V, Roy A. Masks in COVID-19 pandemic: Are we doing it right? J Family Med Prim Care. 2020 Oct; 9(10): 5122-5126. https://doi.org/10.4103/jfmpc.jfmpc_657_20

8. Bhattacharjee S, Bahl P, Chughtai AA, MacIntyre CR. Last-resort strategies during mask shortages: optimal design features of cloth masks and decontamination of disposable masks during the COVID-19 pandemic. BMJ Open Respiratory Research 2020;7(1). https://doi.org/10.1136/bmjresp-2020-000698

9. Torres T, Ferreira EO, Gonçalo M, Mendes-Bastos P, Selores M, Filipe P. Update on Atopic Dermatitis. Acta Med Port 2019;32(9):606-613. https://doi.org/10.20344/amp.11963

10. Rademaker M. Perioral dermatitis. Harpers Textbook of Pediatric Dermatology 2019:338-341.

https://doi.org/10.1002/9781119142812.ch26

\section{COSMETOLOGISTS ' VIEWS ON SOLUTIONS TO SKIN PROBLEMS CAUSED BY WEARING PROTECTIVE FACE MASKS}

L. Valatkevičienė, Ž. Mickienė, E. Petruškevičiūtė

Keywords: cosmetologists, opinion, protective face masks, skin problems.

Summary

March 2020 The World Health Organisation has declared COVID-19 a global pandemic. Wearing protective masks for long periods of time can lead to new or exacerbated skin problems. This is an important issue for people who are obliged to wear face protection and who experience new-onset or exacerbated skin problems as a result of their use. The aim of the study was to find out the opinion of beauticians on the solutions to skin problems caused by the wearing of protective face masks. The study found that clients with oily or problematic skin are most likely to experience the appearance of skin couperose, dehydration and acne due to the use of protective face masks. Respondents mostly recommend products that are moisturising, anti-inflammatory and antibacterial. For inflammatory skin conditions, respondents recommend visiting a dermatologist.

Correspondence to: loreta.valatkeviciene@go.kauko.lt

Gauta 2021-10-26 